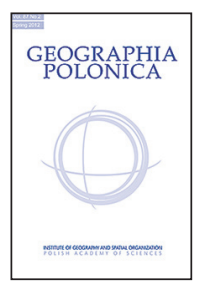 \\ INSTITUTE OF GEOGRAPHY AND SPATIAL ORGANIZATION \\ POLISH ACADEMY OF SCIENCES \\ www.igipz.pan.pl \\ www.geographiapolonica.pl
}

\title{
THE ETHNIC STRUCTURE OF POLAND IN GEOGRAPHICAL RESEARCH
}

\author{
Marek Barwiński \\ University of Łódź \\ Faculty of Geographical Sciences \\ Kopcińskiego 31, 90-142 Łódź: Poland \\ e-mail: marbar@geo.uni.lodz.pl
}

\begin{abstract}
The article reviews geographical research into the ethnic structure in Poland carried out between the nineteenth century and the beginning of the second decade of the twenty-first century, on this basis identifying and citing the main research trends to ethnic studies engaged in by both historians and sociologists. The author presents what he considers the most important research topics to be addressed in further studies on the ethnic and ethno-regional minorities living in today's Poland. Varied research methods are discussed, along with their benefits and limitations, and the paper concludes with a presentation of the main conditions influencing dynamic transformations of the ethnic structure in Poland, as well as the most important characteristics of the relationship between the Polish state and ethnic minorities.
\end{abstract}

\section{Key words}

ethnic minorities - ethnic structure of Poland - political geography

\section{Introduction}

The issue of ethnicity is interdisciplinary, and has thus been tackled by a range of disciplines including history, statistics, demography, political science, sociology, ethnology or ethnography, as well as geography, which focuses primarily on the spatial element of the distribution of ethnicities, the causes and consequences of changes therein and the genesis of concentrations of ethnic minorities. As part of population geography or, more broadly, anthropogeography, and apart from the geographies of religion and languages, there is a discipline called the geography of ethnicity, which studies the sizes of ethnic populations, as well as assessing and analysing ethnic structures on various spatial scales. Studies of ethnic structures and their transformations are especially common in political geography, which devotes more place to the issues of ethnic, linguistic and religious minorities than any other geographical science. Owing to its ability to study the spatial and 
temporal contexts to various phenomena, this discipline facilitates the recognition and comprehension of relationships between political, demographic, social and cultural factors. Such studies are particularly justified in the case of clear dependent relationships between ethnic transformations and territorial or political transitions, i.e. elements within political geography's scope of interest ${ }^{1}$.

Studies in Polish geography concerning ethnic minorities have had a long research tradition and generated great scientific achievements, especially in the interwar period and in the last twenty years ${ }^{2}$. Furthermore, while they were episodic in Communist times, these studies have been experiencing a contemporary renaissance.

When dealing with issues of ethnicity, geography draws on the achievements of other disciplines, especially history, statistics, sociology, and political science. The main point of reference in any analyses of ethnic specifics is space, the geographical environment and the socio-economic circumstances, with simultaneous consideration also given to the influence of historical and political conditions. Close links between political and historical geography reflecting both disciplines' study of natural variability over time and space allow for the kind of referencing of the sociohistorical context that is indispensable in this kind of research.

\section{Literature overview}

An overview of research into the ethnic structure of Poland is impossible without the presentation of current scientific work connected directly with these issues, as well as the compilation of an extensive catalogue of monographs and articles presented in what is certainly still an incomplete list of references.

In the nineteenth century, the ethnic minorities living in Poland were only rarely the

1 Ethnic geography was discussed by such authors as Zaborski and Wrzosek (1939), Maryański (1988) and Eberhardt (2010b).

2 Authors writing extensively on this subject include Eberhardt (2004a, 2010b) and Sobczyński (2008a,b). subject of scientific studies. Polish researchers from the turn of the nineteenth and twentieth centuries (including Buzek, Czyński, Rapacki, Rehman, Romer and Weinfeld) obviously recognised the role and scientific importance of ethnicity but, due to the political conditions at the time, undertook research on the distribution and size of the Polish population in the separate partitioned parts, while omitting ethnic minorities. However, the second half of the nineteenth century did bring modern censusing of the Austrian and Prussian partitions, which asked, inter alia, about ethnic characteristics. The first census in the territory annexed by Russia took place in 1897 . The publication of its results gave geographers statistical documentation allowing for analysis of ethnic structure, not only in Poland but also in the whole of Central Europe. These data were inter alia made use of in Romer's Atlases.

As a an independent Republic of Poland re-emerged and re-formed by way of wars with neighbours and plebiscites, as well as the inclusion of ethnically diverse regions, the issues of ethnic, religious and linguistic minorities came to represent some of the most important research topics in Polish geography, often in the context of the struggle for recognition of the Polish identity in the eastern borderlands. Nevertheless, the beginning of the 20th century and the interwar period can be said to have produced rather few works directly dealing with ethnic minorities. Rather, they work concentrated on issues of the Polish population, understandably enough in the context of the then dynamic political situation. The most important works surely include Wakar's (1917-1918) Rozwój terytorialny narodowości polskiej (Territorial development of Polish nationality), which brought a description and assessment of the ethnic structure of Poland in the late 19th and early 20th centuries, as well as in disputed lands with high ethnic diversity.

Extensive information concerning the ethnic structure of interwar Poland can in turn be found in atlases and maps showing the distribution and population of individual 
ethnic groups ${ }^{3}$. Ethnic minorities of the eastern borderland were discussed by Krysiński (1928a,b), among others, and in a broader spatial context, in Urbański's Mniejszości narodowe $w$ Polsce (National minorities in Poland) (1932). Articles relating to the ethnic structure of eastern Poland were published by such geographers as Wasowicz $(1927,1928)$ and Smoleński (1921, 1929, 1933, 1935). In turn, geographers Leszczycki (1935) and Goetel (1935), as well as ethnographer Reinfuss (1949, 1990), who published his work after the war, conducted research in the Lemkivshchyna - i.e. the land of the Lemko people. The geography, demography and ethnography of the eastern Carpathians, and especially their Ukrainian population, were discussed by Kubijowicz (1921, 1924, 1927). More information can be found in numerous studies by historian and political activist Wasilewski (1917, 1925, 1927), as regards the political and ethnic relationships between Poland, Lithuania and Belarus; including his monumental work on the theoretical issued of ethnicity Sprawy narodowościowe $w$ teorji i w życiu (Nationality issues in theory and in life) (1929). Valuable sources from this period also include statistical and analytical studies of the Polish census data from 1921 and 1931 carried out by Zaborski (1937), among others. Moreover, in the years 1927-1939, the Institute of Ethnic Studies published an Ethnic Affairs quarterly which included work by sociologists, historians, demographers, ethnographers and some geographers, such as Ormicki and Smoleński.

For many years after World War II, scientists did not engage in the study of Poland's ethnic structure. Naturally, this phenomenon mainly reflected political factors and the constraints of censorship. In the new political situation, the prevalent thesis held that Poland had become a single-nation country in the light of changes to its borders and farreaching relocations of population. Any works concerning ethnic minorities were thus 'politically harmful'. Indeed, the deportations and

3 These have been summarised by Gawryszewski (1969, 1995). resettlement that had taken place were also taboo topics. Obstructed access to source materials and the lack of statistical data were also a significant hindrance 4 .

The first scientific studies on ethnic minorities in Poland therefore appeared as late as in the 1960s and 1970s. Noteworthy works are those of Kersten (1963, 1974), mainly concerning Jewish and German minorities; Kwilecki (1963, 1964, 1970, 1974) concerning the Lemkos; Maryański (1962), Biernacka (1973) and Wojecki (1975) concerning Greeks; and Byczkowski (1976) about ethnic minorities in European countries. These were augmented by monographs of broader scope both thematically and spatially by Maryański (1977, 1988).

Where theoretical studies are concerned, we should highlight especially the sociological analyses of the evolution of the notion of nation and ethnic minority by Wiatr (1973) and Ossowski (1984). However, it must be conceded that most work on the post-War situation of ethnic minorities in Poland written in this period was bout the 'shaping and strengthening' of socialist power, and hence written in the spirit of official propaganda. Their educational value is thus extremely limited.

In the second half of the 1980s, several monographs were written by historians on ethnic minorities in the inter-War period, including a very one-sided, left-wing study by Bergman (1984) on Belarusians; a history of the Lithuanian minority by Makowski (1986);

\footnotetext{
4 The question of nationality was included in the first post-War 'summary census' in 1946. However, its results are unreliable and unsuitable for any analysis of Polish ethnic structure at the time. The census was organised primarily to determine the population loss caused by war and occupation, the current population and distribution of Poles, and the German population to be displaced. In addition, it was carried out in a very unstable, dynamic demographic situation, during the on-going resettlement of the population, and the census questionnaire distinguished only Poles, Germans and 'others', as well as people undergoing rehabilitation or verification procedures. In turn, subsequent censuses carried out between 1950 and 1988, did not include questions on nationality, language and religion (Olejnik 2003; Gawryszewski 2005).
} 
and the works by Tomaszewski $(1985 a, b)$ discussing the distribution and social structure of individual minority groups, and including an exceptionally interesting and critical analysis of the results of the interwar censuses. These works are an inspiration to the thorough and careful interpretation of the results of modern censuses.

Research has re-intensified considerably in the years since 1989. Once again, the decisive factor has been political, with democratisation taking place, censorship abandoned and wider access at last being granted to archival sources. The systemic change has restored full freedom to conduct scientific research and there has been a renaissance of ethnic studies. To some extent, this has been 'provoked' by the growing activity and aspirations of individual ethnic minorities, even small ones. Many academic centres (including Łódź, Warsaw, Krakow, Białystok, Opole, Wrocław, Lublin and Zielona Góra) embarked upon research into ethnic and religious minorities. In some cases (e.g. Opole, Białystok, Wrocław and Lublin), this was due to close proximity of areas inhabited by a nonPolish population, in others (Łódź) it reflected institutional changes and the establishment of the Department of Political Geography and Regional Studies, University of Łódź in 1992, with employees and students actively engaged in current research on national, ethnic and religious minorities. In 1992 in Poznań, Ethnic Affairs was reactivated, with articles concerning various aspects of Polish ethnic structure also appearing in various geographical, historical and sociological periodicals. Despite the small number of minorities in modern Poland, the subject has become very popular, even though it relates to individual minorities to varied degrees. Most works have in practice been devoted to the Jewish, German and Ukrainian minorities.

Many valuable materials, data and analyses can be found in collective works, including those edited by Kurcz (1997), Madajczyk (1998) and Berdychowska (1998), or penned by Chałupczak and Browarek (1998), as well as two studies edited by Dudra and Nitschke
(2010, 2013). These works attempt to generalise as regards ethnic affairs in post-War Poland, gathering in one publication the results of works from many scientists specialising in minority issues. They show changes in the political, organisational, social and demographic situation of non-Polish ethnicities, as well as the evolution of the sense of national identity. Issues regarding the attitudes of the state authorities and Polish society towards minorities as the various political changes took hold are especially interesting, though rarely discussed in the previous era.

Geographers mainly examine minorities from the spatial, demographic and regional points of view. An extensive chapter devoted to the ethnic structure of Poland was included in the monograph Ludność Polski w XX wieku (The Population of Poland in the 20th Century) by Gawryszewski (2005). Especially noteworthy is a series of works by Eberhardt devoted initially to the ethnic structure of Belarus (1994a), Ukraine (1994b) and Lithuania (1998), then to the ethnic transformations of the whole of Central and Eastern Europe in the 20th century - Między Rosja a Niemcami (Between Russia and Germany) (1996). Another of Eberhardt's works, Migracje polityczne na ziemiach polskich (1939-1950) (Political migrations on Polish territories) (2010) is a valuable geographical study concerning resettlements and deportations of Polish citizens. Sobczyński (2000) presented the contemporary religious diversity of Polish society against a backdrop of its ethnic structure. He also engaged in critical analysis of the prevailing stereotypes connecting certain denominations to adherence to certain ethnicities. The transformations of Polish ethnic structure in the 20th century were also discussed by Eberhardt (2006, 2008) and, in relation to religious structure, Rykała (2006, 2011). In discussing voting geography in Poland, Kowalski (1998a, 2000) and Matykowski (1994, 1997, 2008) pointed to characteristic electoral behaviour of selected ethnic and religious minorities.

There have also been attempts at geographical and political analysis of the impact 
of political transformations on ethnic structure, especially in the territorial-quantitative and political-organisational contexts, both relating to all ethnicities living in Poland and individual minorities (including Janicki 1999, 2000; Flaga 2002; Barwiński 2008a,b, 2010, 2011; Rykała 2008c). A synthetic geopolitical and geo-historical approach to ethnic issues against the backdrop of post-war political and social change was presented in monographs by Barwiński $(2004,2013)$ concerning ethnic minorities within the eastern Polish population, and Rykała (2007) in relation to the Jewish population.

Studies concerning the role of ethnic minorities in the organisation of urban space, and the cultural heritage stemming from their existence, also play a significant role among geographical works (including Liszewski 1991; Rykała 2003, 2008b, 2010; Kulesza \& Koter 2005; Kulesza \& Rykała 2006, 2009; Baranowska \& Rykała 2009; Kulesza 2010; Rykała \& Barwiński 2010).

Owing to the fact that political geography inter alia combines studies concerning borders, borderlands and ethnic minorities, there are numerous geographical works analysing ethnic structure in contemporary border areas, be these: Polish-German (including Szczepankiewicz-Battek 2001, 2003, 2005), Polish-Czech (including Heffner 1991, 1998; Siwek 1996, 2005; Heffner \& Solga 2003), Polish-Slovak (including Sobczyński \& Zawadzka 1988; Barwiński 1999, 2003, 2012b; Soja 2001, 2010), Polish-Ukrainian (including Koszałka \& Soja 2003; Barwiński 2009b), Polish-Belarusian (including Barwiński 2001, 2005a,b; Kowalski 1998b, 2002, 2006) or Polish-Lithuanian (including Eberhardt 1997; Kowalski 1999; Rykała 2008a; Barwiński 2009c, 2014b).

The publication of the results of the 2002 and 2011 censuses, which included a question concerning ethnicity, represented both a great statistical facilitator and an impulse for further work. It allowed for the verification of previous subjective estimates, as well as for presentation of a critical analysis of both the population and contemporary distribution of ethnic minorities in Poland. Such works have inter alia been developed by geographers such as Barwiński (2006, 2009a, 2014a), Rykała (2006, 2014) and Szczygielski (2006), by the sociologists Babiński (2004) and Adamczuk and Łodziński (2006), by historian Chałupczak (2006) and by demographer Wysocki (2006, 2010).

Especially noteworthy among the theoretical geographical studies are those proposing a typology for ethnic minorities from the ethnic-territorial and genetic points of view (Koter 1993), as well as a typology for borderlands, along with the minorities inhabiting them (Koter 1995a,b, 1998). In addition, Sobczyński (1993, 2012) made an attempt at a methodology by which ethnic and religious minorities might be studied in Polish research circumstances.

The issue of ethnic minorities in Poland, though undoubtedly of interest to political geography in both theoretical and empirical terms, was not discussed at all in the academic textbooks by Barbag (1987) and Otok (2004), while only having a couple of pages devoted to it by Rykiel (2006).

The situation of the national and ethnic minorities living in Poland is also the subject of historical research. Historians with greatest achievements in this field include Chałupczak, Drozd, Dudra, Janusz, Madajczyk, Mironowicz, Misiło, Olejnik, Tarka, Tomaszewski and Waldenberg. Most of these workers only attempted the study and analysis of single minorities. Publications concerning multiple minorities have been more scarce, and have usually been included in collective works.

Not all ethnic minorities have been equally represented in scientific publications. Indeed, in line with their importance to the political, social and economic life of the country, their potential for generating conflict, historical events and population, most historians have focused on issues relating to Germans, Jews and Ukrainians in Poland. In the case of Ukrainian affairs, many of the historians involved are from the community in question (examples include Drozd, Halczak, Hałagida, Hawryluk and Misiło). Thus, 
while the work of these scientists is cognitively valuable and based on sound research, it can sometimes be burdened by subjectivity and one-sidedness of judgment. For example, there is a tendency for the Polish authorities to be blamed for any harm suffered by Ukrainians in the post-War years, while the impact of military action by Ukrainian troops on the behaviour of the Polish authorities and Polish society towards Ukrainians is left trivialised. That there was persecution of Ukrainians in Poland in the mid-twentieth century is an undisputed fact, but it is not fact that can be considered in isolation of the circumstances leading up to it.

Among the numerous historical works concerning the post-War and contemporary lives of individual ethnic minorities, the monographs on Belarusians (Mironowicz 1992, 1993), Karaites and Armenians (Pełczyński 1995, 1997, 2004), Lithuanians (Tarka 1998), the Lemko (Dudra 2008) Germans (Matelski 1999; Madajczyk 2001), Ukrainians (Misiło 1992, 1996; Drozd 1997, 2001, 2013; Hawryluk 1999; Hałagida 2002; Pisuliński 2009; Drozd \& Halczak 2010; Motyka 2011) and Jews (Kersten 1992; Tomaszewski 1993) are especially valuable. In recent years, there have also been works on the persecution of ethnic minorities by the Communist 'security forces', which are based on analyses of documents from the Institute of $\mathrm{Na}$ tional Remembrance (including Milewski \& Pyżewska 2005; Słabig 2008; Syrnyk 2009; Wysocki 2011; Hytrek-Hryciuk \& Straucholda \& Syrnyk 2011). A number of studies and expert opinions on the changing legal aspects conditioning the situation of minorities have been published by Janusz, with these culminating in the monumental monograph Ochrona praw mniejszości narodowych w Europie (The protection of the rights of national minorities in Europe) (2011).

In the first years of the twenty-first century, two extensive monographs on the ethnic policy issues of the Polish authorities in the post-War period were published: Polityka narodowościowa PRL (Policy on nationality in the Polish People's Republic) by Mironowicz
(2000) and Polityka narodowościowa Polski w latach 1944-1960 (The nationality policy of Poland in the years 1944-1960) by Olejnik (2003). Developed by historians on the basis of a comprehensive analysis of archival source materials, these constitute a very valuable source of factual information. The former, notwithstanding its title, focuses on the two decades following the War, with later years discussed briefly and the analysis ending in the 1970s, thereby not covering the whole period in existence of the Polish People's Republic. Moreover, the author completely omits several smaller ethnic minorities, while showing a clear preference for issues relating to the Belarusian minority, which is very prominently represented in his scientific work. In turn, as its title suggests, Olejnik's work confines itself to the first dozen years immediately after the War. This is justifiable, since for historians dealing with the transformations of the ethnic situation in Poland this is undoubtedly the most interesting period and one for which an understanding is indispensable if the subsequent decades are to be analysed.

Historical works focus primarily on presenting the facts, the historical background, and - very importantly - the relationship between the Polish majority and various minorities. However, certain decades gain disproportionate attention, as the vast majority of studies focus on the situation of ethnic minorities immediately after the War and in the 1950s, the period of the most dramatic changes and events. The Third Republic is treated very superficially, even though the early 1990s brought about significant changes in the situation of non-Polish ethnicities who should finally be the subject of a greater number of historical studies after more than 20 years.

In addition to geographical and historical works on Polish ethnic structure, studies done by sociologists are also very useful in contributing to a full and comprehensive understanding of the specificities of individual minority groups. Sociological studies can be seen at the theoretical and empirical level. The theoretical 
work concerns, among other things, the methodology of ethnic studies; the definitions of certain notions; the broader social, cultural and ethnic aspects; the typology of ethnic minorities and the relationships with the majority and their country of residence; as well as national identity, its formation and transformation. Among the numerous works of this type, the publications by Znaniecki (1990), Kłoskowska (1996), Babiński (1998), Żelazny (2004), Posern-Zieliński (2005) and Budyta-Budzyńska (2010) are especially noteworthy.

Apart from general and theoretical topics, sociologists are also preoccupied with practical and empirical studies of the ethnically, religiously and culturally diverse regions present in Poland. These studies are based largely on the results of fieldwork engaged in directly among representatives of minority groups. They are thus of high cognitive value. The following studies are particularly noteworthy: Mirga and Mróz (1994) on Roma, Tobjański (1994), on the Czech minority, Kurcz (1995), on the German minority, Warmińska (1999) on Tatars, and Sadowski (1991, 1995). Babiński (1997) and Wojakowski (2002) focused on the issue of the Polish-Belarusian and Polish-Ukrainian border, while Domagała (1996), Sakson (1998) and Berlińska (1999) studied ethnic relations in the Warmia and Mazury and Opole regions, putting particular emphasis on the role of the German minority. Finally, Michna $(1995,2004)$ considered the Lemko against a broader background of ethnic transformations in the Ruthenian population of Carpathia.

Another subject raised by sociologists and political scientists after 1990 concerns relations between the state and minorities. The impact of regulatory, systemic and political changes on the relations between the ethnic minorities and the Polish state during the past 20 years has been carefully presented, among others, by Budyta-Budzyńska (2003) and Łodziński (2005), as well as in the work edited by Nijakowski (2005). On the other hand, political scientist Żołędowski (2003) discussed this type of issue as exemplified by the Belarusian and Lithuanian minorities in Poland and the Polish minority in Belarus and Lithuania.

We should also mention the publications of the Central Statistical Office (GUS) released cyclically (every three years since 1993) containing information on the population and territorial structure of all registered denominations and national and ethnic associations in Poland. The Parliamentary Committee on National and Ethnic Minorities has been publishing joint works since 2010 on individual ethnic minorities. Works on Belarusians, Czechs, Lemkos, Karaites and Lithuanians have already been published.

The above, surely-incomplete review of scientific works on the ethnic structure of Poland shows a clear domination of studies on the socalled traditional minorities, with few studies relating directly to regional groups ${ }^{5}$. In recent years, due to a large number of people declaring Silesian and Kashubian ethnicities in censuses, as well as in consequence of growing social and political aspirations of leaders of these communities, more and more work (mostly of a sociological and historical nature) is being done on the contemporary situation of Silesians (Nijakowski 2004; Szmeja 2005; Sakson 2008; Dolińska 2009 and Janicki 2009) and Kashubians (including Borzyszkowski et al. 1999 and Obracht-Prondzyński 2002, 2007a,b, 2008).

\section{The basic research issues concerning Poland's ethnic structure}

During the past few decades, Poland has gone through numerous significant political, economic and social transformations - from the formation of its borders, resettlements, the imposition of Communism, through the growing surveillance of party authorities and security forces over all forms of activity, to democratisation and liberalisation of the

\footnotetext{
5 This applies to studies dealing with their contemporary political and national aspirations, as the work discussing the history, cultural heritage and folklore of these groups is very extensive.
} 
political system and integration with the political, economic and military structures of Western Europe. These transformations, often implemented through revolution, not evolution, had to have an impact on the situation of ethnic minorities, who in fact went through significant alterations of their distribution, population, identity, relations with the Polish majority, legal situation, organisation, cultural activities and education. The effect was not consistent in the long temporal, territorial and ethnic perspective. It differed over time, in different regions of Poland and in relation to different ethnicities. The main turning points coincided with the crises and political breakthroughs that sparked activity in ethnic minorities, often resulting in regulatory and practical changes to the treatment of non-Polish citizens.

Geographical, historical and sociological studies most often focus on the so-called traditional, historical minorities living in Poland for centuries and serving as relics of the multinational Republic (Jews, Germans, Ukrainians, Belarusians, Lithuanians, Armenians, Russians, Czechs, Slovaks, Lemkos, Tartars, Roma and Karaites). As a result of World War II and the policy of the Communist authorities, these minorities underwent significant territorial, quantitative, institutional, social and cultural transformations. Regions inhabited by them have often been divided by state borders, with the population impacted by resettlement on various scales and having their sense of national identity weakened by assimilation policies as part of an attempt to build a mono-ethnic society. All these elements contribute to the natural scientific interest in these ethnicities.

The so-called regional minorities, or rather ethnic-regional minorities, sometimes also called 'postulated minorities' are studied less frequently. They are often seen (and studied and described), not in national terms, but only in ethnographic and cultural terms, which today is an anachronism. Since the beginning of the twenty-first century, we have been seeing a marked increase in political and national inspirations, correlated with the dynamically growing population and diversity of regional groups defining themselves in national categories. The results of the latest census in 2011 showed not only the total numerical dominance in the national structure of the Silesians and Kashubians, but also the emergence for the first time in the history of censuses in Poland of further very diverse regional groups, though to a marginal extent (such as Kociewiacy, Highlanders, Wielkopolanie, Mazurians, Zagłębiakowie, Borowiakowie, Masovians and Kurpie people) $)^{6}$. Though they are several times more numerous than other traditional minorities and more organisationally, socially and politically active than many, Silesians and Kashubians are still far less frequently subjects for scientists studying ethnic affairs. It seems that one of the main reasons for this is the continuing unwillingness to perceive and define ethno-regional minorities in national terms, and thus non-inclusion in studies on ethnic structure. The intensification of research on ethno-regional groups, particularly as regards their national and political aspirations, and their relation to the Polish state, as well as the origins and manifestations of their self-identification, represents one of the major challenges faced by scientists studying aspects of the contemporary national diversity of Poland.

Researchers also rarely discuss the socalled new minorities, or the more and more numerous groups of economic (less often, political) migrants from post-Soviet, Asian and African countries (mainly Vietnamese, Chinese, Arabs, Indians and Chechens). The development of this type of research is important, especially because these communities, in contrast to the traditional and regional minorities, are usually completely culturally and socially different, isolated and often not integrated into the majority, this contributing to a persistence of conflicts and negative stereotypes.

\footnotetext{
${ }^{6}$ The main reason for such a large increase in the number and diversity of regional groups was a different census methodology used in 2011, especially the opportunity afforded for people to declare double national identities.
} 
The transformations of Polish ethnic structure starting with the territorial and political changes of World War II did not end with the political and systemic transformation of the 1990s. The political, legal and institutional reality changed, with a clear departure from earlier ethnic policies. The communities of various minorities became more active, though this did not quench old conflicts and grudges, and nor did it stop the processes of assimilation and acculturation. The results of censuses conducted in the early twenty-first century have provided often disputed and controversial data concerning the population and distribution of individual ethnicities. They also showed a highly dynamic increase in the sense of belonging to ethno-regional minorities. The recognition of the ethnic diversity of Poland by the democratic authorities, the introduction of compromise legal solutions, and the presence of ethnic minorities in public space have all resulted in changes in the relationships between non-Polish ethnicities and the majority, which on one hand leads to the former's empowerment and, on the other to critical opinions and conflicts, especially on the local level.

After several decades and numerous transformations in the political and legal situation, we can attempt to study the ways in which state politics, in both the totalitarian and democratic system, influence ethnic structure. How do the political system and its changes determine the relationship between the majority and minorities? How did the national identity and institutionalisation of social and cultural activity of ethnic minorities 'sentenced' by the authorities to disperse and assimilate gradually change in various periods? What were the main causes of the diverse socio-political situation of minorities in Polish People's Republic? Did the systemic changes started in 1989 allow for equal treatment of ethnic minorities in practice? How do minority leaders perceive and assess the current situation of the nationalities they represent? What are the current main disputes and conflicts in the relations between minorities and the Polish state, as well as between minorities and Polish society?
What factors most affect the changes in the population, distribution and concentration of non-Polish nationalities today? How do the methods used in the Polish censuses actually create ethnic structure in Poland? What is the role of ethnic minorities in Polish foreign policy, especially towards its neighbours? How does the influx of immigrants from non-European countries influence cultural, economic and social transformations? What are the causes and consequences of the very dynamic growth in the number and diversity of ethnic and regional minorities? How much does the ongoing regionalisation of the European Union contribute to that? What are the components of the sense of identity of individual ethno-regional groups? Does the dominance of regional minorities in the ethnic structure of Poland give rise to a tendency for autonomy or separatism to be fought for? Will the ongoing political, economic and cultural integration, globalisation and unification of Europe contribute to the total ethnic uniformisation of Poland, or will it result in a rebirth of various types of ethnic identity and the intensification of regionalisms? What roles should national, ethnic and regional minorities play in the politics, economy and social life of Poland in the subsequent decades of the 21 st century?

These questions are - and should continue to be - the main research topics addressed by geographical and political studies on the contemporary ethnic structure of Poland.

\section{Methods of researching ethnic affairs}

The study of ethnic affairs is hindered by numerous factors, of which one of the most important is that basic problem for science in general, the maintenance of objectivity and diligence, and the eschewal or removal of bias.

The difficulties scientists studying ethnicity issues encounter can be broadly divided into endogenous and exogenous (Sobczyński \& Grabowska 1993; Sobczyński 2012). As the overcoming of endogenous barriers has a crucial influence on research, they are 
the more important category. No researcher is free of national affiliation or, for example, upbringing in a given religion. These are determinants representing a serious encumbrance that are present regardless of whether the given researcher is from the majority group in society or from some minority group. The main endogenous barrier and chief hindrance to the study of ethnic minorities is of this kind, and - if it is to be overcome - the researcher must reject his/her own individual approach to reality in favour of an ideological neutrality that makes more objective presentation of the facts a possibility. This is in fact more crucial in ethnic studies than in many other disciplines (Sobczyński \& Grabowska 1993).

The group of exogenous barriers is significantly more extensive and largely dependent on the current socio-political situation. Included here is access to objective and solid statistical documentation (there were no statistical data on ethnic structure in Poland before the 2002 census), state policy towards minorities (especially oppressive in the circumstances of totalitarianism), and the spatial distribution of ethnic minorities. However, the most major problem entails overcoming the mistrust of respondents. Just as the main endogenous barrier involves a researcher achieving a distancing from his/her ethnic and religious identity, so the main exogenous social barrier is the analogous identity of the object of the study, i.e. the representative of a minority. For, although research into a minority without personal contact with representatives thereof is a theoretical possibility, the cognitive value of a study done in this way must be low. Equally, it is particularly hard to achieve effective study of minorities that have negative historical experiences, have suffered ill-treatment and persecution from the state or the majority in society, and are afraid of a renewal of nationalist tendencies (Sobczyński \& Grabowska 1993). Unfortunately, these circumstances apply in regard to the vast majority of non-Polish ethnicities in Poland.

In minority studies, the research context and the interaction between the researcher and the subject are always encumbered by ethnic circumstances and the 'our-foreign' dichotomy, so it is especially important to consider the social background of a given research situation as this stems from the political, cultural, religious and ethnic conditions. In the context of ongoing democratisation, minority respondents' distrust and fear of expressing their views and attitudes seem to be waning (Sobczyński 2012). An objective and thorough evaluation of the relationship between the majority and the ethnic minority in a country is further hampered by different objectives, interests and points of view on both sides. An ethnic minority always operates with a sense of danger that identity might be lost, and is prone to perceive state policies as purposeful assimilation strategies. On the other hand, the dominant ethnicity often fails to understand, disrespects or does not see the problems experienced by minorities (Halczak 2006).

Studies of ethnic or regional minorities in Poland are most often limited to a single minority, geographical region or political and historical period. In collective studies concerning multiple minorities, individual ethnicities are not only presented by different authors, but also from different points of view and using different methods, a circumstance that greatly hinders comparative analyses. It is usually associated with a clear 'specialisation' of certain researchers and, apart from the high factual value of individual studies, is a deficiency of the whole body of work concerning the ethnic structure of Poland.

Of greater cognitive value are syntheses discussing a wide range of circumstances in the diverse situation of individual minorities, using a comparative method to analyse political, ethnic and social processes in aspects that are temporal (between subsequent 'decades of political transformations'), geographical (between different regions of Poland and administrative units) or ethnic (between different ethnic and regional minorities). A comparative study allows for the drawing of a number of conclusions that relate to the past and contemporary 
socio-political situations of minorities, as well as facilitating the presentation of projections. This type of synthetic study also facilitates the preservation of objectivity and allows us to curb the stereotypes and generalisations. The various nationalities living in Poland are not isolated in society, and from one another (in the geographical, political, economic, social and cultural sense), they interact in various ways, are impacted upon by the same political and economic processes and should thus be studied as part of comparative research in the widest temporal, spatial and ethnic context.

The basic starting point for geographical studies of ethnic structure in Poland is an analysis and a synthesis of the source material, especially historical, contained in archives and the scientific literature. Reference to historical materials is essential for solid presentation of political, ethnic and social transformations among ethnic minorities.

The results of the 2002 and 2011 censuses offered a relatively new starting point and a database for certain analyses, especially of a spatial nature. Owing to the political and legal changes in Poland, they were the first censuses in dozens of years to include two ethnicity criteria: nationality and language, which allowed, inter alia, for verification of earlier subjective estimates concerning the sizes of ethnic minorities, as well as the development of a cartographic presentation of ethnic structure in Poland and changes therein in the first decade of the 21st century. Unfortunately each of these two censuses used different methods to present data and estimate the population of individual minorities - a fact that hindered, though did not entirely prevent, comparative studies. In any case, the results of the two censuses as regards ethnicity, and the procedures used to obtain them proved controversial and were criticised widely?. As was rightfully noted by Tomaszewski (1985a,b, 1991), Eberhardt (1996), Chałupczak and Browarek (1998) and

\footnotetext{
7 Among those to have discussed it intensively is Barwiński (2013, pp. 237-308).
}

Gawryszewski (2005), all ethnic statistics concern matters that are very delicate, subjective and unmeasurable. It is therefore normal for them to be 'erroneous' in some way, ensuring that results will inevitably be met with greater or lesser emotion and controversy, as well as necessitating careful interpretation. In addition, their credibility is often a reflection of current state policy in the period of the census. Despite that, the ethnicity statistics in question are a very important research tool, not just in the quantitative sense, but also in the vital spatial sense, since they allow geographers to use cartographic methods in showing the distribution of ethnic minorities. This is all the more important given that such a tool was not available in Poland for decades.

Statistical data obtained in the course of the censuses also allow us to use spatial analysis (GIS), and the methods of deriving such values as spatial concentration or centrographic measures that it provides. The main limitation in using spatial analysis is the incompleteness and lack of comparability of gathered and processed data, and the information released by GUS (especially in the context of the last two censuses), as well as the often excessively general spatial scope.

Geographical field studies related to sociological qualitative and quantitative studies are especially important as we seek to verify and supplement data on the current situation of ethnic minorities, as well as learn the attitudes and opinions of representatives of nationalities under study. Interviews with the leaders of minority organisations are especially valuable. Good results are achieved using the so-called in-depth interview method, which entails the subject being interviewed on the basis of a script confined to open questions that provide full freedom of expression and guarantee comparability. During this type of interview, the researcher traces the answers and asks more in-depth questions to obtain more precise data. The purposeful choice of subjects is meant to learn the opinions of the most active and most competent group of members of an ethnic 
organisation, and to compare the views of the leaders of organisations of the same and different minorities. The interviews may relate to such subjects as the functioning of individual organisations and their spatial structures; the main demands as regards local and central authorities; the most important conflict points, successes and failures of certain organisations; cooperation with other ethnic organisations; possible support from the mother country; the perception of influence of political transformations on the past and current situation of the minority; as well as opinions on the results of censuses and the functioning of the Ethnic Minorities Act. Even the relatively sparse interviews with the leaders of ethnic communities (qualitative studies), who are usually well-informed about the problems of the community they represent, can yield better results than wide-ranging sociological studies among all representatives of a given ethnic minority (quantitative studies), though the final choice of the most suitable method depends on the type of information sought. In addition, data collected in the course of quantitative studies (such as surveys or questionnaire interviews) may later be processed using statistical methods, and presented using various cartographic methods, in such a way that their value is enhanced. However, the information obtained during direct talks with representatives of national minorities should be interpreted with caution, given a context that reflects ethnic, religious, cultural, political and social circumstances. The results can be heavily encumbered by the ethnic and religious affiliation of the researcher, the current political situation and the method of sample selection. Notwithstanding these reservations, studies based on personal contact between the researcher and the representatives of a minority are very valuable, especially given that the quality of the statistical data provided by GUS is worse than expected, and that the democratisation and liberalisation of Poland has largely abated the fear of expressing independent views once experienced by the representatives of minorities.

\section{Conclusions}

The universality of the processes of social globalisation and unification, as well as the dominance of mass culture, all result in an enhanced need to belong to a local homeland, with the ongoing political and economic integration of Europe definitely causing a turn towards ethnicity, and hence growing interest in the problems of small ethnic, cultural and regional communities. In Central and Eastern Europe, the return to ethnic issues has additionally been amplified by the geographical, political and geopolitical transitions of the early 1990s. The issue of national diversity, suppressed, marginalised or totally ignored under totalitarianism, became an element of the internal and foreign policies of individual states. Harmonious relationships between different ethnic groups in communist countries turned out to be yet another propagandist myth, whose collapse led to the disintegration of multinational states and numerous armed conflicts in the Balkans and the former Soviet Union.

In the case of Poland, the transition from what was seemingly an ethnically unified country into one with a greater recognition of its actual diversity, along with the empowerment of ethnic minorities and their ensuing presence in public life, have provided the main spark underpinning a renewed interest on the part of scientists, as well as renewed emotion in local communities themselves, largely on account of the small size and high level of dispersion of the minorities in question. Due to their limited demographic, economic and political potential, national and ethnic minorities do not pose a threat to the territorial and political integrity of Poland, nor to the dominance of the Polish language and culture. On the contrary: the Polish state, with its population, economic, cultural, linguistic and media potential, its education system, and its sections of society manifesting nationalist attitudes all pose a real threat to the ethnic and cultural identity of the few and dispersed minorities.

Despite some differences, all of the so-called traditional minorities are heavily integrated 
into the Polish society, if we define integration as "participation in the life of the majority and the co-creation of the majority culture without the imposition of their own models" (Budyta-Budzyńska 2010). These groups are not isolated in either the geographical, political, social, cultural or economic senses of the term.

We can say universal (at least sociologically universal) models of integration of minority groups apply to the Muslims in Western Europe, the Roma in Central Europe, maybe the Vietnamese in Poland, but surely not to the Germans, Ukrainians, Belarusians, Jews, Lithuanians, Silesians or Kashubians in Poland.

Despite that, Poland will not avoid becoming multicultural, albeit to a more limited extent than Western Europe, as none of the minorities will ever completely emigrate or assimilate. But real multiethnicity is a marginal phenomenon and, despite its recent political and systemic transformations, Poland remains one of the most homogeneous states in the world.

The main factor in the ethnic transformations in Poland was and remains the state policy toward minorities, in senses both negative (pre-1989) and positive (since the early 1990s). The political decisions of the last couple of decades have resulted directly in significant changes to the distribution, territorial concentration and size of ethnic minority communities, as well as their legal and institutional situation. Policies have been impacted upon very significantly by the less or more justified fears of the authorities of some minorities (mainly Germans and Ukrainians) or their sympathy for others (such as Belarusians and Greeks). The diverse assessments of potential threats and the potential 'usefulness' of different minorities has resulted in diversified state policies towards all members of a given community.

The discriminatory and assimilation actions of the communist authorities against ethnic minorities were tolerated and sometimes even supported by society (as with the postWar resettlements, or the anti-Semitic campaigns of 1956 and 1968). This support often reflected the (successful) use of nationalist rhetoric by the authorities, with political enemies being targeted on many occasions, with a view to social discontent being channelled against a 'non-Polish' population. Opposition groups - be they the armed organisations of the 1940s or the political ones of the 1980s - have a negative or at best neutral attitude towards ethnic minorities, only sporadically doing anything to acknowledge the Polish citizens of non-Polish ethnicity ${ }^{8}$. As a result, ethnic minorities were inclined to treat the political opposition of the 1980s with distrust and reserve, first and foremost in line with its being perceived as a nationalist and Catholic movement. Certain leaders of the Ukrainian community deriving from the student anti-communist movement were the exception testing this rule.

Since the early 1990s, the political and legal situation of ethnic minorities has been improving markedly, with the result being empowerment and institutional pluralisation. This was associated with changes in the attitudes of minorities and their relations with the majority of Polish society. Various ethnicities took advantage of the new legal, political and economic circumstances in different ways. They mainly focused on territorial concentration (a far more important factor than population size), identity (national, linguistic, religious or cultural), internal integration (especially institutional), activity (both of the elites and members) and relationships with foreign homelands (in terms of intensity and character).

Territorially concentrated communities of clear ethnic and linguistic identity, with well-developed education and organisation, and support from the institutions and citizens of their homeland (e.g. Germans and Lithuanians) are able to use their legal privileges (especially under the provisions of the Act on $\mathrm{Na}$ tional and Ethnic Minorities and Regional

\footnotetext{
8 Some political exceptions include the introduction of a resolution on ethnic minorities at the first Solidarity Congress convened in 1981 or during the election campaign in 1989, as well as the inclusion of Ukrainian activists among the candidates of the Solidarity Citizens' Committee.
} 
Language), and are able to maintain their own individuality and identity. A greater threat of assimilation is posed to minorities scattered as a result of resettlement (Ukrainians), additionally ethnically divided and diversified, as well as institutionally dispersed (the Lemko people), or else facing greater organisational problems (as regards their associations, education or participation in local government) and having far fewer opportunities to benefit from their legal privileges. On the other hand, even a relatively large population, territorial concentration and direct closeness to the homeland (Belarus) do not guarantee ethnic identity. The main obstacles are passiveness and a susceptibility to assimilation, low group integration (with the exception of religious integration), as well as a lack of support from and identification with the foreign homeland.

Ethno-regional minorities, especially Silesian, are a different matter. Redefining the identity and aspirations from an regionalcultural group into an ethnic-regional group is not only met with resistance in parts of Polish society and among politicians. but also causes divisions among Silesians themselves. The recognition or non-recognition of the Silesian nationality raised a lot of controversy and conflict from the mid-1990s onwards. These disputes intensified after the 2002 and 2011 censuses, in which Silesian was the non-Polish nationality declared most widely. However, a growing number of Silesian identifications did not change the legal status, as this is still not an officially recognised ethnic minority (even though it in fact meets all the conditions provided for in Polish law), and the Silesian language used by over 500,000 people (according to the 2011 census) still fails to enjoy regional language status, unlike Kashubian (with around 100,000 speakers) $)^{9}$. The lack of under-

\footnotetext{
${ }^{9}$ As a result of the effort by Silesian activists and multiple court appeals, an Association of People of Silesian Nationality was registered on 7 September 2012, though this has still not resolved the matter of the formal and official recognition of Silesian nationality. On 5 December 2013, the Supreme Court held that the Silesians cannot be considered a separate nation, with the effect that the Association of People of Silesian Nationality should not be registered under this name.
}

standing of Silesian national aspirations, mainly caused by the lack of knowledge of the complex history of various regions in Poland, seems to be the most important factor mobilising and unifying Silesians.

Ethnic, national and regional minorities do not by definition have a dominant role in the country. As in many other countries, the national majority in Poland imposes legal, social and cultural standards. In a democratic state, the dominance of the majority does not have to mean discrimination and impairment of the minority, but rather shows its natural demographic, linguistic, political and cultural advantage. The state provides citizens with equal rights and prohibits discrimination, while requiring everyone, including citizens of other nationalities, to be loyal and obedient to the law. However, political and legal equality is not equivalent to actual equality in the use of language, cultivation of customs and imposing of cultural models, especially in the case of such clear population disproportions between the dominant nation and the minorities.

It is not therefore enough for the ethnic and national minorities living within a nation state to be tolerated. Rather they have to be offered additional support and protection. This also applies to legal-political realities of the democratic and liberal Poland. As the fourth President of the US James Madison said in the early 19th century, the majority can ignore the interests and rights of the minority, so the latter should be protected, even in a democracy. Despite the passage of 200 years, these words still remain relevant. The relationship between the dominant nation and the minorities is a separate issue. They are only partially dependent on the legal regulations and state administration's actions, while the changes of social attitudes among the majority and minority represent a slow and drawn-out process encumbered by stereotypes and history.

The vast majority of national, ethnic and regional minorities living in contemporary Poland are a part of the historical, cultural and political heritage of Poland, a testament to the former complexity and multicultural 
nature of Poland, and a part of that country's history, present day and, hopefully also future. These minorities, even though thought of as 'different' and separate in regards to their national, linguistic or religious identity are 'at home', with all the rights and obligations that that entails.

Further research into the ethnic structure of Poland is therefore essential, mainly because of the dynamic (quantitative, qualitative, territorial, institutional, cultural, social and political) changes the country is currently

\section{References}

AdAMcZUK L., ŁoDZIŃSKI S. (eds.), 2006. Mniejszości narodowe w Polsce w świetle Narodowego Spisu Powszechnego z 2002 roku. Warszawa: Wydawnictwo Naukowe Scholar.

BABIŃSKI G., 1997. Pogranicze polsko-ukraińskie. Etniczność, zróżnicowanie religijne, tożsamość. Kraków: Nomos.

BABIŃSKI G., 1998. Metodologiczne problemy badań etnicznych. Kraków: Nomos.

BABIŃSKI G., 2004. Mniejszości narodowe i etniczne w Polsce w świetle spisu ludności z roku 2002. Studia Socjologiczne, 1 (172), pp. 139-152.

BARANOWSKA M., RYKAŁA A., 2009. Multicultural city in a United Europe - the case of Łódź [in:] M. Sobczyński (ed.), Historical regions divided by the borders. General problems and regional issue, Region and Regionalism, no. 9, vol. 1, Łódź-Opole: University of Łódź. Department of Political Geography and Regional Studies, Silesian Institute in Opole, pp. 257-268.

BARBAG J., 1987. Geografia polityczna ogólna. Warszawa: Państwowe Wydawnictwo Naukowe.

BARWIŃSKI M., 1999. Współczesna tożsamość etniczna i kulturowa Łemków na obszarze Łemkowszczyzny - uwarunkowania i konsekwencje [in:] Acta Universitatis Lodziensis. Folia Geographica Socio-Oeconomica, no. 2, Łódź: Uniwersytet Łódzki, pp. 53-69.

BarWIŃSKI M., 2001. Contemporary national and religious diversification of inhabitants of the Polish-Belorussian borderland - the case of Hajnówka district [in:] M. Koter, K. Heffner (eds.), undergoing, as well as the growing importance of native regional groups and nationalities stemming from the non-European cultures, and the geopolitical, economic and civilisation transformations that are changing Europe.

\section{Acknowledgements}

Article written as part of research sponsored by a National Science Centre grant based on decision no. DEC-2011/01/B/HS4/02609.

Changing role of border areas and regional policies, Region and Regionalism, 5, Opole-Łódź: University of Łódź. Department of Political Geography and Regional Studies, Silesian Institute in Opole, pp. 180-184.

BARWIŃSKI M., 2003. Lemkos as a small relict nation [in:] M. Koter, K. Heffner (eds.), The role of ethnic minorities in border regions, Region and Regionalism, no. 6, vol. 1, Łódź-Opole: University of Łódź. Department of Political Geography and Regional Studies, Silesian Institute in Opole, pp. 39-47.

BARWIŃ́SKI M., 2004. Podlasie jako pogranicze narodowościowo-wyznaniowe. Łódź: Wydawnictwo Uniwersytetu Łódzkiego.

BARWIŃSKI M., 2005a. Współczesne stosunki narodowościowo-religijne na Podlasiu [in:] M. Malikowski, D. Wojakowski (eds.), Granice i pogranicza nowej Unii Europejskiej. Z badań regionalnych, etnicznych i lokalnych, Kraków: Nomos, pp. 172-194.

BARWINSKI M., 2005b. The contemporary ethnic and religious borderland in Podlasie Region [in:] M. Koter, K. Heffner (eds.), Historical, ethnic and geographical problems of borderlands, Region and Regionalism, no. 7, vol. 2, Opole-Łódź: University of Łódź. Department of Political Geography and Regional Studies, Silesian Institute in Opole, pp. 81-90.

BARWIŃSKI M., 2006. Liczebność i rozmieszczenie mniejszości narodowych $i$ etnicznych w Polsce w 2002 roku a wcześniejsze szacunki [in:] M. Bieńkowska-Ptasznik, K. Krzysztofek, A. Sadowski (eds.), Obywatelstwo i tożsamość 
w społeczeństwach zróżnicowanych kulturowo i na pograniczach, 1, Białystok: Wydawnictwo Uniwersytetu w Białymstoku, pp. 345-370.

BARWIŃSKI M., 2008a. Konsekwencje zmian granic i przekształceń politycznych po II wojnie światowej na liczebność i rozmieszczenie Ukraińców, Łemków, Białorusinów i Litwinów w Polsce [in:] P. Eberhardt (ed.), Problematyka geopolityczna ziem polskich, Prace Geograficzne, 218, Warszawa: Instytut Geografii i Przestrzennego Zagospodarowania PAN, pp. 217-236.

BARWIŃSKI M., 2008b. Wpływ granic oraz uwarunkowań politycznych na zmiany struktury narodowościowej i wyznaniowej na przykładzie Podlasia [in:] M. Kulesza (ed.), Czas i przestrzeń w naukach geograficznych. Wybrane problemy geografii historycznej, Łódź: Wydawnictwo Uniwersytetu Łódzkiego, pp. 48-65.

BARWIŃSKI M., 2009a. Rozmieszczenie i liczebność Łemków w Polsce na podstawie wyników spisu powszechnego z 2002 roku - uwarunkowania i kontrowersje [in:] S. Dudra, B. Halczak, I. Betko, M. Smigiel (eds.), Łemkowie, Bojkowie, Rusini - historia, współczesność, kultura materialna i duchowa, 2, Zielona Góra: Druk-Ar, pp. 15-28.

BARWINSSKI M., 2009b. The contemporary Polish-Ukrainian borderland - its political and national aspect [in:] M. Sobczyński (ed.), Historical regions divided by the borders. General problems and regional issue, Region and Regionalism, no. 9, vol. 1, Łódź-Opole: University of Łódź. Department of Political Geography and Regional Studies, Silesian Institute in Opole, pp. 187-208.

BARWIŃSKI M., 2009c. Mniejszość litewska na tle przemian politycznych Polski po II wojnie światowej [in:] M. Kulesza (ed.), Geografia historyczna jako determinanta rozwoju nauk humanistycznych, Legnica-Łódź: PWSZ im. Witelona w Legnicy, Katedra Geografii Politycznej i Studiów Regionalnych Uniwersytetu Łódzkiego, pp. 48-65.

BARWIŃSKI M., 2010. Changes in the social, political and legal situation of national and ethnic minorities in Poland after 1990 [in:] J. Kitowski (ed.), 20 years of socio-economic transformations in countries of Central and Eastern Europe - an attempt of accounts, Geopolitical Studies, 16, Warszawa: Instytut Geografii i Przestrzennego Zagospodarowania PAN, pp. 223-244.

BARWIŃSKI M., 2011. Ukraińcy na Podlasiu - geneza, kontrowersje, wspótczesność. Acta Universitatis Lodziensis. Folia Geographica Socio-Oeconomica, 11, Łódź: Uniwersytet Łódzki, pp. 123-144.
BARWIŃSKI M., 2012a. Łemkowszczyzna jako region etniczno-historyczny [in:] A. Pawłowska, Z. Rykiel (eds.), Region i regionalizm w socjologii i politologii, Rzeszów: Wydawnictwo Uniwersytetu Rzeszowskiego, pp. 136-154.

BARWIŃSKI M., 2012b. Stosunki międzypaństwowe Polski z Ukrainq, Białorusiq i Litwa po 1990 roku w kontekście sytuacji mniejszości narodowych. Studia z Geografii Politycznej i Historycznej, 1, Łódź: Wydawnictwo Uniwersytetu Łódzkiego, pp. 139-166.

BARWIŃSKI M., 2013. Geograficzno-polityczne uwarunkowania sytuacji Ukraińców, Łemków, Białorusinów i Litwinów w Polsce po 1944 roku. Łódź: Wydawnictwo Uniwersytetu Łódzkiego.

BARWIŃSKI M., 2014a. Struktura narodowościowa Polski w świetle wyników spisu powszechnego z 2011 roku. Przegląd Geograficzny, vol. 86, no. 2, pp. 217-241.

BARWIŃSKI M., 2014b. Mniejszość litewska w Polsce. Studium przypadku gminy Puńsk. Studia Obszarów Wiejskich, 34, Warszawa, pp. 137-153.

BeRDYCHOWsKA B. (ed.), 1998. Mniejszości narodowe w Polsce. Praktyka po 1989 r. Warszawa: Wydawnictwo Sejmowe, Centrum Stosunków Międzynarodowych Instytutu Spraw Publicznych.

BerLIŃSKA D., 1999. Mniejszośćniemiecka na Ślasku Opolskim w poszukiwaniu tożsamości. Opole: Instytut Śląski w Opolu.

BieRnACKA M., 1973. Osady uchodźców greckich w Bieszczadach. Etnografia Polska, vol. 17, no. 1, Warszawa, pp. 83-94.

Borzyszkowski J., Mordawski J., Treder J., 1999. Historia, geografia, język i piśmiennictwo Kaszubów. Gdańsk: Wydawnictwo M. Rożak.

BudYTA-BudZYŃ́SKA M., 2003. Mniejszości narodowe - bogactwo czy problem? Instytucjonalizacja mniejszości narodowych w Polsce w latach 1989-2002. Warszawa: Instytut Studiów Politycznych PAN.

BudYTA-BudzyŃSKa M., 2010. Socjologia narodu i konfliktów etnicznych. Warszawa: Wydawnictwo Naukowe PWN.

BYcZKowskI J., 1976. Mniejszości narodowe w Europie 1945-1974 (wybrane zagadnienia). Opole: Instytut Śląski w Opolu.

ChatupCZAK H., 2006. Liczba mniejszości narodowych $i$ etnicznych $w$ Polsce $w$ świetle powszechnego spisu ludności z 2002 roku oraz badań naukowych [in:] E. Michalik, H. Chałupczak (eds.), 
Mniejszości narodowe i etniczne w procesach transformacji oraz integracji, Lublin: Wydawnictwo UMCS, pp. 263-270.

Chatupczak H., Browarek T., 1998. Mniejszości narodowe w Polsce 1918-1995. Lublin: Wydawnictwo UMCS.

CZAJKowskI J. (ed.), 1992. Łemkowie w historii i kulturze Karpat. Część pierwsza. Rzeszów: Editions Spotkania.

DoliŃSKA K., 2009. Potoczny i ideologiczny poziom doświadczania ślaskości. Ślqzacy w poszukiwaniu odrębności? Wrocław: Wydawnictwo Uniwersytetu Wrocławskiego.

Domagata B., 1996. Mniejszość niemiecka na Warmii i Mazurach. Rodowód kulturowy, organizacja, tożsamość. Olsztyn: Ośrodek Badań Naukowych im. Wojciecha Kętrzyńskiego.

Drozd R., 1997. Droga na zachód. Osadnictwo ludności ukraińskiej na ziemiach zachodnich i północnych Polski w ramach akcji "Wisła”. Warszawa: Tyrsa.

DrozD R., 2001. Polityka władz wobec ludności ukraińskiej w Polsce w latach 1944-1989. Warszawa: Tyrsa.

Drozd R., 2013. Ukraińcy w Polsce wobec swojej przeszłości (1974-2005). Warszawa: Tyrsa.

Drozd R., Halczak B., 2010. Dzieje Ukraińców w Polsce w latach 1921-1989. Warszawa: Tyrsa.

DUDRA S., 2008. Poza mała ojczyznq. Łemkowie na Ziemi Lubuskiej. Wrocław: Oficyna Wydawnicza Atut.

Dudra S., Nitschke B. (eds.), 2010. Mniejszości narodowe $i$ etniczne w Polsce po II wojnie światowej. Kraków: Nomos.

DudRa S., NitsCHKE B. (eds.), 2013. Stowarzyszenia mniejszości narodowych, etnicznych i postulowanych w Polsce po II wojnie światowej. Kraków: Nomos.

Eberhardt P., 1994a. Przemiany narodowościowe na Białorusi. Warszawa: Editions Spotkania.

EberHARDT P., 1994b. Przemiany narodowościowe na Ukrainie XX wieku. Warszawa: Biblioteka "Obozu".

Eberhardt P., 1996. Między Rosja a Niemcami. Warszawa: Wydawnictwo Naukowe PWN.

Eberhardt P., 1997. Problematyka demograficzna pogranicza polsko-litewskiego. Przegląd Geograficzny, vol. 69, no. 1-2, pp. 28-51.
EberHARDT P., 1998. Przemiany narodowościowe na Litwie. Warszawa: Przegląd Wschodni.

EberHARDt P., 2006. Przemiany struktury etnicznej ludności Polski w XX wieku. Sprawy Narodowościowe. Seria Nowa, 28, pp. 53-74.

EBERHARDT P., 2008. Struktura narodowościowa ludności Polski. Rocznik Nauk Społecznych, vol. 36, no. 1, pp. 145-170.

EBERHARDT P., 2009. Liczebność i rozmieszczenie ludności ukraińskiej na przełomie XX i XXI wieku. Sprawy Narodowościowe. Seria Nowa, 35, pp. 49-64.

EBERHARDT P., 2010a. Migracje polityczne na ziemiach polskich (1939-1950). Poznań: Instytut Zachodni.

EBERHARDT P., 2010b. Osiagnięcia naukowe polskiej geografii narodowości. Czasopismo Geograficzne, vol. 81, no. 3, pp. 139-152.

FlaGa M., 2002. Mniejszość karaimska w Polsce w przeszłości i obecnie. Czasopismo Geograficzne, vol. 73, no. 1-2, pp.13-25.

GAWRYSZEWSKI A., 1969. Polskie mapy narodowościowe, wyznaniowe i językowe. Bibliografia (lata 1827-1967). Dokumentacja Geograficzna, 4, Warszawa: Instytut Geografii i Przestrzennego Zagospodarowania PAN.

GAWRYSZEWSKI A., 1995. Mapy narodowościowe, wyznaniowe $i$ językowe Polski wykonane przez autorów obcych. Bibliografia (lata 1846-1967). Dokumentacja Geograficzna, 3, Warszawa: Instytut Geografii i Przestrzennego Zagospodarowania PAN.

GaWriszewski A., 2005. Ludność Polski w XX wieku. Monografie IGiPZ PAN, 5, Warszawa: Instytut Geografii i Przestrzennego Zagospodarowania PAN.

Goetel W., 1935. O Łemkowszczyźnie. Kraków: Polskie Towarzystwo Tatrzańskie.

HalczAK B., 2006. O konieczności prowadzenia badan porównawczych nad mniejszościami narodowymi w Europie Środkowo-Wschodniej [in:] B. Halczak (ed.), Mniejszości narodowe w Europie Środkowo-Wschodniej po upadku komunizmu, Zielona Góra: Uniwersytet Zielonogórski, pp. 9-16.

HatAGIDA I., 2002. Ukraińcy na ziemiach zachodnich i północnych Polski 1947-1957. Warszawa: Instytut Pamięci Narodowej.

HaWrYLuk J., 1999. „Kraje ruskie Bielsk, Mielnik, Drohiczyn": Rusini-Ukraińcy na Podlaszu - fakty 
i kontrowersje. Kraków: Fundacja Świętego Włodzimierza Chrzciciela Rusi Kijowskiej.

Heffner K., 1991. Śląsk Opolski. Proces przekształceń ludnościowych i przestrzennych systemu osadnictwa wiejskiego. Opole: Instytut Ślaski w Opolu.

Heffner K. (ed.), 1998. Kluczowe problemy demograficzno-osadnicze obszarów przygranicznych Polska-Czechy. Opole: Instytut Śląski w Opolu.

Heffner K., Solga B., 2003. The German minority of Opole Silesia as a minority of social and cultural borderland [in:] M. Koter, K. Heffner (eds.), The role of ethnic minorities in border regions, Region and Regionalism, no. 6, vol. 1, Łódź-Opole: University of Łódź. Department of Political Geography and Regional Studies, Silesian Institute in Opole, pp. 73-81.

HoŁuszKo M., 1993. Mniejszości narodowe i etniczne w Polsce. Społeczeństwo Otwarte, 2, Warszawa.

Hytrek-Hryciuk J., Strauchold G., Syrnyk J. (eds.), 2011. Internacjonalizm czy...? Działania organów bezpieczeństwa państw komunistycznych wobec mniejszości narodowych (1944-1989). Warszawa-Wrocław: Instytut Pamięci Narodowej.

JANICKI W., 1999. The distribution and significance of Tatar ethnic group in Poland [in:] Koter M., K. Heffner (eds.), Multicultural Regions and Cities, Region and Regionalism, 4, Opole-Łódź: University of Łódź. Department of Political Geography and Regional Studies, Silesian Institute in Opole, pp. 146-153.

JANICKI W., 2000. Tatarzy w Polsce - naród, grupa etniczna czy 'ludzie pogranicza'? Czasopismo Geograficzne, vol. 71, no.2, Warszawa, pp. 173-181.

JANICKI W., 2009. Minority recognition in nationstates - the case of Silesians in Poland [in:] Drobik T., Šumberová M. (eds.), Chapters of modern human geographical thought, Newcastle: Cambridge Scholar Publishing, pp. 155-184.

Janusz G., 2011. Ochrona praw mniejszości narodowych w Europie. Lublin: Wydawnictwo UMCS.

KeRSTEN K., 1963. Migracje powojenne w Polsce. Próba klasyfikacji i ogólna charakterystyka zewnętrznych ruchów ludności [in:] Polska Ludowa: Materiały i Studia, 2, Warszawa, pp. 3-26.

KeRsten K., 1974. Kształtowanie stosunków ludnościowych [in:] Polska Ludowa 1944-1950. Przemiany społeczne. Wrocław: Zakład Narodowy im. Ossolińskich, pp. 74-176.
Kersten K., 1992. Polacy, Żydzi, komunizm. Anatomia półprawd 1939-1968. Warszawa: Niezależna Oficyna Wydawnicza.

KŁosKowSKA A., 1996. Kultury narodowe u korzeni. Warszawa: Wydawnictwo Naukowe PWN.

KoszatKa M., Soja M., 2003. The Bojko Region extinct ethnic region of the Polish Carpathians [in:] M. Koter, K. Heffner (eds.), The role of ethnic minorities in border regions, Region and Regionalism, no. 6, vol. 1, Łódź-Opole: University of Łódź. Department of Political Geography and Regional Studies. Silesian Institute in Opole, pp. 48-54.

KOTER M, 1993. Geographical classifications of ethnic minorities [in:] A. Gosar (ed.), Geography and ethnicity, Geographica Slovenica, 24, Ljubljana, pp. 123-138.

KOTER M., 1995a. Ludność pogranicza - próba klasyfikacji genetycznej, Acta Universitatis Lodziensis. Folia Geographica. 20, Łódź: Uniwersytet Łódzki, pp. 239-246.

KOTER M., 1995b. A genetic classification of frontier peoples and multicultural border zones in Poland, Bohemia and Slovakia [in:] V. Baran (ed.), The boundaries and their impact on the territorial structure of region and state, Acta Universitatis Matthiae Belli. Geographical Studies, 1, Banska Bystrica: Univerzita Mateja Bela, pp. 37-45.

Koter M., 1998. Frontier peoples - origin and classification [in:] M. Koter, K. Heffner (eds.), Borderlands or transborder regions - geographical, social and political problems, Region and Regionalism, 3, Opole-Łódź: University of Łódź. Department of Political Geography and Regional Studies, Silesian Institute in Opole, pp. 28-38.

KOWALSKI M., 1998a. Wyznanie a preferencje wyborcze mieszkańców Białostocczyzny (19901997). Przegląd Geograficzny, vol. 70, no. 3-4, pp. 269-282.

KOWALSKI M., 1998b. Problematyka etniczna wschodniego pogranicza Polski [in:] J. Kitowski (ed.), Czynniki i bariery regionalnej współpracy transgranicznej. Próba syntezy, Rzeszów: Wydział Ekonomiczny Filii UMCS w Rzeszowie, pp. 285-294.

KOWALSKI M., 1999. Kulturowe uwarunkowania stosunków polsko-litewsko-białoruskich [in:] J. Kitowski (ed.), Problematyka geopolityczna Europy Środkowej i Wschodniej, Rozprawy i Monografie 
Wydziału Ekonomicznego, 18, Rzeszów: Wydział Ekonomiczny Filii UMCS w Rzeszowie, pp. 77-88.

KowalSKI M., 2000. Geografia wyborcza Polski. Przestrzenne zróżnicowanie zachowań wyborczych Polaków w latach 1989-1998. Geopolitical Studies, 7, Warszawa: Instytut Geografii i Przestrzennego Zagospodarowania PAN.

KoWALSKI M., 2002. Mniejszość polska na Grodzieńszczyźnie, mniejszość białoruska na Białostocczyźnie [in:] C. Sadowska-Snarska (ed.), Problemy rozwoju przygranicznych regionów wschodniej Polski, Białystok: Wyższa Szkoła Ekonomiczna w Białymstoku, pp. 89-106.

KoWALSKI M., 2006. Belarusians in Białystok region [in:] J. Kitowski (ed.), Regional transboundary cooperation in countries of Central and Eastern Europe - a balance of achievements, Geopolitical Studies, 14, Warszawa: Instytut Geografii i Przestrzennego Zagospodarowania PAN, pp. 477-487.

KRYSIŃSKI A., 1928a. Liczba i rozmieszczenie Białorusinów w Polsce. Sprawy Narodowościowe, 3-4, Warszawa: Instytut Badań Spraw Narodowościowych, pp. 351-378.

KRYSIŃSKI A., 1928b. Liczba i rozmieszczenie Ukraińców w Polsce. Sprawy Narodowościowe, 6, Warszawa: Instytut Badań Spraw Narodowościowych.

Kubijowicz W., 1921. Przyczynek do antropogeografii Gorganów. Przegląd Geograficzny, 2, Warszawa: Polskie Towarzystwo Geograficzne, pp. 146-149.

KubIJowicz W., 1924. Rozmieszczenie kultur i ludności w Karpatach Wschodnich. Kraków: Księgarnia Geograficzna Orbis.

KuBIJOWICZ W., 1927. Życie pasterskie w Beskidach Magurskich. Kraków: Prace Komisji Etnograficznej PAU.

KulESZA M., 2010. To po nich pozostało... (ślady wielowyznaniowej Łodzi we współczesnym krajobrazie kulturowym miasta) [in:] M. Kulesza, M. Łapa, J. Walicki (eds.), Rola wspólnot wyznaniowych w historii miasta Łodzi, Łódź: Ibidem, pp. 241-326.

Kulesza M., Koter M., 2005. Ślady wielonarodowej $i$ wielowyznaniowej Łodzi we wspótczesnym krajobrazie kulturowym miasta [in:] M. Koter, M. Kulesza, W. Puś, S. Pytlas (eds.), Wpływ wielonarodowego dziedzictwa kulturowego Łodzi na współczesne oblicze miasta, Łódź: Wydawnictwo Uniwersytetu Łódzkiego, pp. 137-300.
Kulesza M., Rykata A., 2006. Przeszłość i teraźniejszość - wpływ wielonarodowego dziedzictwa kulturowego na współczesny krajobraz miast Polski Środkowej [in:] Acta Facultatis Studiorum Humanitatis et Naturae Universitatis Prešoviensis. Folia Geographica, 10, pp. 300-308.

Kurcz Z., 1995. Mniejszość niemiecka w Polsce. Wrocław: Wydawnictwo Uniwersytetu Wrocławskiego.

KURCZZ. (ed.), 1997. Mniejszości narodowe w Polsce. Wrocław: Wydawnictwo Uniwersytetu Wrocławskiego.

KWILECKI A., 1963. Mniejszości narodowe w Polsce Ludowej. Kultura i Społeczeństwo, 4, pp. 85-103.

KWILECKI A., 1964. Problemy asymilacji mniejszości narodowych na Ziemiach Zachodnich na przykładzie Łemków. Warszawa: Państwowe Wydawnictwo Naukowe.

KWILECKI A., 1970. Fragmenty najnowszej historii Łemków. Warszawa: Państwowe Wydawnictwo Naukowe.

KWILECKI A., 1974. Łemkowie. Zagadnienia migracji i asymilacji. Warszawa: Państwowe Wydawnictwo Naukowe.

LeszCZYCKI S., 1935. Zarys antropologiczny Łemkowszczyzny. Kraków: Wierchy.

LISZEWSKI S., 1991. Rola społeczności żydowskiej w organizacji przestrzeni miejskiej Łodzi [in:] S. Liszewski, W. Puś (eds.), Dzieje Żydów w Łodzi 1820-1944. Wybrane problemy, Łódź: Wydawnictwo Uniwersytetu Łódzkiego.

ŁoDZIŃSKI S., 2002. Ochrona praw osób należacych do mniejszości narodowych $i$ etnicznych - perspektywa europejska. Warszawa: Wydawnictwo Naukowe Scholar.

ŁODZIŃSKI S., 2005. Równość i różnica. Mniejszości narodowe w porzadku demokratycznym w Polsce po 1989 roku. Warszawa: Wydawnictwo Naukowe Scholar.

MadAuczYK P. (ed.), 1998. Mniejszości narodowe w Polsce. Państwo i społeczeństwo polskie a mniejszości narodowe w okresach przełomów politycznych (1944-1989). Warszawa: Instytut Studiów Politycznych PAN.

Madauczyk P., 2001. Niemcy polscy 1944-1989. Warszawa: Oficyna Naukowa.

MakowskI B., 1986. Litwini w Polsce 1920-1939. Warszawa: Państwowe Wydawnictwo Naukowe.

MARYAŃSKI A., 1962. Mniejszość grecka w województwie rzeszowskim. Czasopismo Geograficzne, vol. 33, no. 3, pp. 362-363. 
MaRYAŃSKI A., 1977. Ludność świata. Warszawa: Państwowe Wydawnictwo Naukowe.

MarYAŃSKI A., 1988. Narodowości świata. Warszawa: Państwowe Wydawnictwo Naukowe.

MatelSKI D., 1999. Niemcy w Polsce w XX wieku. Warszawa: Państwowe Wydawnictwo Naukowe.

MATYKOWSKI R., 1997. Udział i zróżnicowanie poparcia mniejszości narodowych w Polsce w wyborach parlamentarnych z dnia 21 września 1997 roku. Sprawy Narodowościowe. Nowa Seria, vol. 6, no. 2, pp. 261-272.

MatYKOWSKI R., 2008. Przestrzenne zróżnicowanie w zachowaniach wyborczych mieszkańców województwa podlaskiego [in:] D. Świqutek, M. Bednarek, P. Siłka (eds.), Współczesne problemy badawcze geografii polskiej - geografia człowieka, Dokumentacja Geograficzna, 36, Warszawa: Instytut Geografii i Przestrzennego Zagospodarowania, pp. 28-33.

Matykowski R., TobolskA A., 1994. Mniejszości narodowe $w$ Polsce $w$ świetle wyników wyborów do Sejmu z dnia 27 października 1991 roku. Sprawy Narodowościowe. Seria Nowa, vol. 3, no. 1, pp. 131-143.

Michna E., 1995. Łemkowie. Grupa etniczna czy naród? Kraków: Nomos.

Michna E., 2004. Kwestie etniczno-narodowościowe na pograniczu słowiańszczyzny wschodniej i zachodniej. Ruch rusiński na Stowacji, Ukrainie i w Polsce. Kraków: Polska Akademia Umiejętności.

Milewski J., PYżEWSKA A. (eds.), 2005. Stosunki polsko-białoruskie w województwie białostockim w latach 1939-1956. Warszawa: Instytut Pamięci Narodowej.

Mirga A., Mróz L., 1994. Cyganie. Odmienność i nietolerancja. Warszawa: Wydawnictwo Naukowe PWN.

MiRONOWicz E., 1992. Świadomość narodowa spoteczności prawosławnej Białostocczyzny. Zeszyty Naukowe Instytutu Nauk Politycznych UW, 17, Warszawa, pp. 109-142.

Mironowicz E., 1993. Białorusini w Polsce 19441949. Warszawa: Wydawnictwo Naukowe PWN.

MiRONOWICZ E., 2000. Polityka narodowościowa PRL. Białystok: Białoruskie Towarzystwo Historyczne.

MısıŁO E., 1993. Akcja "Wisła". Dokumenty. Warszawa: Wydawnictwo "Archiwum Ukraińskie".

MısıŁO E., 1996. Repatriacja czy deportacja: Przesiedlenia Ukraińców z Polski do USRR 1944-1946.
Vol. 1. Dokumenty 1944-1945, Warszawa: Wydawnictwo "Archiwum Ukraińskie".

MotyKA G., 2011. Od rzezi wotyńskiej do akcji "Wisła". Konflikt polsko-ukraiński 1943-1947. Kraków: Wydawnictwo Literackie.

NiJakowski L. (ed.), 2004. Nadciagaja Ślq̨zacy. Czy istnieje narodowość ślaska? Warszawa: Wydawnictwo Naukowe Scholar.

NiJAKOWski L. (ed.), 2005. Polityka państwa polskiego wobec mniejszości narodowych i etnicznych. Komisja Mniejszości Narodowych i Etnicznych, Warszawa: Wydawnictwo Sejmowe.

NIJAKOWSKI L., ŁodzIŃSKI S. (eds.), 2003. Mniejszości narodowe i etniczne w Polsce. Informator 2003. Komisja Mniejszości Narodowych i Etnicznych, Warszawa: Wydawnictwo Sejmowe.

Obracht-ProndzYŃSKI C., 2002. Kaszubi - między dyskryminacja a regionalna podmiotowościa. Gdańsk: Instytut Kaszubski, Uniwersytet Gdański.

Obracht-Prondzrński C. (ed.), 2007a. Kim sq Kaszubi? Nowe tendencje w badaniach społecznych. Gdańsk: Instytut Kaszubski.

Obracht-Prondzrński C., 2007b. Kaszubi dzisiaj. Kultura - język - tożsamość. Gdańsk: Instytut Kaszubski.

Obracht-Prondzyński C., 2008. Ruch kaszubsko-pomorski u progu XXI wieku. Stan organizacyjny i dylematy programowe [in:] A. Sakson (ed.), Ślązacy, Kaszubi, Mazurzy i Warmiacy - między polskościq a niemieckościq, Poznań: Instytut Zachodni, pp. 233-242.

OlejNIK L., 2003. Polityka narodowościowa Polski w latach 1944-1960. Łódź: Wydawnictwo Uniwersytetu Łódzkiego.

Ossowski S., 1984. O ojczyźnie i narodzie. Warszawa: Państwowe Wydawnictwo Naukowe.

Оток S., 2004. Geografia polityczna: geopolityka, ekopolityka, globalistyka. Warszawa: Państwowe Wydawnictwo Naukowe.

PeŁczYŃski G., 1995. Najmniejsza z mniejszości. Rzecz o Karaimach polskich. Warszawa: Wydawnictwo Towarzystwa Karpackiego.

PetCZYŃski G., 1997. Ormianie polscy w wieku XX. Problem odrębności etnicznej. Warszawa: Polskie Towarzystwo Ludoznawcze.

PeŁczyński G., 2004. Karaimi polscy. Poznań: Poznańskie Towarzystwo Przyjaciół Nauk.

PISULIŃSKI J., 2009. Przesiedlenia ludności ukraińskiej z Polski do USSR w latach 1944-1947. Rzeszów: Wydawnictwo Uniwersytetu Rzeszowskiego. 
Podlaski K. aka Skaradziński B., 1990. Białorusini, Litwini, Ukraińcy. Białystok: Versus.

Posern-Zielinśki A., 2005. Etniczność. Kategorie. Procesy etniczne. Poznań: Poznańskie Towarzystwo Przyjaciół Nauk.

Puś W., Liszewski S. (eds.), 1991. Dzieje Żydów $w$ Łodzi 1820-1944. Wybrane problemy. Łódź: Wydawnictwo Uniwersytetu Łódzkiego.

REINFUSS R., 1949. Łemkowie jako grupa etnograficzna. Prace i Materiały Etnograficzne, 7, Lublin: Polskie Towarzystwo Ludoznawcze.

ReInfuss R., 1990. Śladami Łemków. Warszawa: Wydawnictwo PTTK Kraj.

RYKAtA A., 2003. Dziedzictwo materialne Żydów w krajobrazie kulturowym województwa tódzkiego [in:] E. Orłowska, J. Klementowski (eds.), Kulturowy aspekt badań geograficznych. Studia teoretyczne i regionalne, Wrocław: Oddział Wrocławski PTG, Uniwersytet Wrocławski.

Rykata A., 2006. Mniejszości religijne w Polsce na tle struktury narodowościowej i etnicznej [in:] M. Bieńkowska-Ptasznik, K. Krzysztofek, A. Sadowski (eds.), Obywatelstwo i tożsamość w społeczeństwach zróżnicowanych kulturowo i na pograniczach. Vol. 1, Białystok: Wydawnictwo Uniwersytetu w Białymstoku, pp. 379-412.

Rykata A., 2007. Przemiany sytuacji społeczno-politycznej mniejszości żydowskiej w Polsce po drugiej wojnie światowej. Łódź: Wydawnictwo Uniwersytetu Łódzkiego.

RYKAłA A., 2008a. Sytuacja społeczno-kulturalna Litwinów w Polsce $i$ ich wpływ na relacje między krajem zamieszkania a Litwa. Acta Universitatis Lodziensis. Folia Geographica Socio-Oeconomica, 9, Łódź: Wydawnictwo Uniwersytetu Łódzkiego, pp. 89-113.

RYKAŁA A., 2008b. Żydowska przestrzeń sakralna dawnej i współczesnej Łodzi na przykładzie synagog i domów modlitwy [in:] M. Kulesza (ed.), Czas i przestrzeń w naukach geograficznych. Wybrane problemy geografii historycznej, Łódź: Wydawnictwo Uniwersytetu Łódzkiego, pp. 103-130.

Rykata A., 2008c. Przemiany sytuacji społeczno-politycznej Karaimów polskich na tle zmian ich przynależności państwowej [in:] P. Eberhardt (ed.), Problematyka geopolityczna ziem polskich, Prace Geograficzne, 218, Warszawa: Instytut Geografii i Przestrzennego Zagospodarowania PAN, pp. 237-266.

RYKAŁA A., 2010. Łódźna mapie skupisk żydowskich Polski (po 1945 r.) [in:] A. Lech, K. Radziszewska,
A. Rykała (eds.), Społeczność żydowska i niemiecka w Łodzi po 1945 roku, Łódź: Wydawnictwo Uniwersytetu Łódzkiego, pp. 267-332.

RYkAtA A., 2011. Mniejszości religijne w Polsce geneza, struktury przestrzenne, tło etniczne. Łódź: Wydawnictwo Uniwersytetu Łódzkiego.

RykatA A., 2014. National, ethnic and religious minorities in contemporary Poland [in:] T. Marszał (ed.), Society and space in contemporary Poland in Łódź University geographical research, Łódź: Łódź University Press, pp. 137-170.

Rykata A., BARWIński M., 2010. Przemiany demograficzno-społeczne i działalność organizacyjna Niemców w Łodzi na tle sytuacji mniejszości niemieckiej w Polsce po 1945 r. [in:] A. Lech, K. Radziszewska, A. Rykała (eds.), Społeczność żydowska i niemiecka w Łodzi po 1945 roku, Łódź: Wydawnictwo Uniwersytetu Łódzkiego, pp. 333-375.

RykAtA A., Kulesza M., 2009. Materialne dziedzictwo Żydów w krajobrazie kulturowym Polski Środkowej [in:] M. Kulesza (ed.), Geografia historyczna jako determinanta rozwoju nauk humanistycznych, Łódź-Legnica: Państwowa Wyższa Szkoła Zawodowa im. Witelona w Legnicy, Katedra Geografii Politycznej i Studiów Regionalnych. Uniwersytet Łódzki, pp. 203-217.

RYKIEL Z., 2006. Podstawy geografii politycznej. Warszawa: Wydawnictwo Naukowe PWN.

SADOWSKI A., 1991. Narody wielkie i małe. Białorusini w Polsce. Kraków: Instytut Religioznawstwa. Uniwersytet Jagielloński.

SAdoWSKI A., 1995. Pogranicze polsko-biatoruskie. Tożsamość mieszkańców. Białystok: Trans Humana.

SAKSON A., 1998. Stosunki narodowościowe na Warmii i Mazurach 1945-1997. Poznań: Instytut Zachodni.

Sakson A. (ed.), 2008. Ślqzacy, Kaszubi, Mazurzy i Warmiacy - między polskościq a niemieckościa . Poznań: Instytut Zachodni.

SienkieWicz W., Hryciuk G. (eds.), 2008. Wysiedlenia, wypędzenia i ucieczki 1939-1959. Atlas ziem Polski. Polacy, Niemcy, Żydzi, Ukraińcy. Warszawa: Demart.

SIWEK T., 1996. Česko-polská etnická hranice. Spisy Filozofické Fakulty Ostravské Univerzity, Ostrava: Ostravská univerzita.

SIWEK T., 2005. Ethnic identity versus declared nationality in the Czech part of Teschen Silesia 
(Zaolzie) [in:] M. Koter, K. Heffner (eds.), Historical, ethnic and geographical problems of borderlands, Region and Regionalism, no. 7, vol. 2, Opole-Łódź: University of Łódź. Department of Political Geography and Regional Studies, Silesian Institute in Opole, pp. 115-122.

Stabig A., 2008. Aparat bezpieczeństwa wobec mniejszości narodowych na Pomorzu Zachodnim w latach 1945-1989. Szczecin: Instytut Pamięci Narodowej.

SMOLEŃSKI J., 1921. W sprawie polskości Ziemi Wileńskiej. Orli Lot, no. 2, pp. 18-20, no. 3, pp. 37-39.

SMOLEŃSKI J., 1929. Mniejszości narodowe w Polsce [in:] Dziesięciolecie Polski Odrodzonej. Księga Pamiątkowa 1918-1928. Kraków-Warszawa: llustrowany Kuryer Codzienny, pp. 43-52.

SMOLEŃSKI J., 1933. Ludność o języku polskim na obszarze Rzeczypospolitej. Kwartalnik Statystyczny, vol. 10, no. 4, Kraków, pp. 439-460.

SMOLEŃSKI J., 1935. Łemkowie i Łemkowszczyzna. Wierchy, 13, Kraków: Polskie Towarzystwo Tatrzańskie, pp. 54-61.

SobCZYŃSKI M., 2000. Struktura narodowościowo-wyznaniowa Polski. Acta Universitatis Lodziensis. Folia Geographica Socio-Oeconomica, 3, Łódź: Wydawnictwo Uniwersytetu Łódzkiego, pp. 157-174.

SOBCZYŃSKI M., 2008a. Historia geografii politycznej [in:] A. Jackowski, S. Liszewski, A. Richling (eds.), Historia geografii polskiej, Warszawa: Wydawnictwo Naukowe PWN, pp. 219-236.

SoBCZYŃSKI M., 2008b. Stan i perspektywy rozwoju geografii politycznej w Polsce [in:] S. Liszewski, J. Łoboda, W. Maik (eds.), Stan i perspektywy rozwoju geografii w Polsce. Raport z pracy Komitetu Nauk Geograficznych Polskiej Akademii Nauk w kadencji 2003-2006, Bydgoszcz: Wydawnictwo Uczelniane Wyższej Szkoły Gospodarki, pp. 188-201.

SOBCZYŃSKI M., 2012. Interakcja "badacz-podmiot badania" w studiach nad mniejszościami narodowymi w Polsce. Studia z Geografii Politycznej i Historycznej, no. 1, Łódź: Wydawnictwo Uniwersytetu Łódzkiego, pp. 95-112.

SobCZYŃSKI M., GrabowSKA E., 1993. Metodologiczne problemy badania mniejszości narodowych i religijnych. Geopolitical and social problems of the former socialistic countries. Conference Papers, Soczewka.
SobcZYŃSkI M., ZawadZKA B., 1988. Orawa Polska. Problemy geograficzno-polityczne i społeczne. Łódź: Zarząd Wojewódzki PTTK. Regionalna Pracownia Krajoznawcza.

SojA M., 2001. The cultural and ethnic diversity of the population of Łemkowszczyzna (Lemko Region) in the 19th and 20th century [in:] M. Koter, K. Heffner (eds.), Changing role of border areas and regional policies, Region and Regionalism, no. 5, Łódź-Opole: University of Łódź. Department of Political Geography and Regional Studies, Silesian Institute in Opole, pp. 212-221.

SoJA M., 2010. Cykle rozwojowe ludności Karpat Polskich w XIX i XX wieku. Kraków: Instytut Geografii i Gospodarki Przestrzennej Uniwersytetu Jagiellońskiego.

StATYSTYKA Polski, 1927. Pierwszy Powszechny Spis Rzeczypospolitej Polskiej z dnia 30 września 1921 roku. Mieszkania. Ludność. Stosunki Zawodowe. Województwo Białostockie. 19, Warszawa: Główny Urząd Statystyczny.

StATYSTYKa Polski, 1938. Drugi Powszechny Spis Ludności z dnia 9 XII 1931 roku. Series C, Warszawa: Główny Urząd Statystyczny.

StATYSTYKa Polski, 1947. Seria D - Powszechny sumaryczny spis ludności z dnia 14 lutego 1946 r. Series D, no. 1, Warszawa: Główny Urząd Statystyczny.

SYRNYK J. (ed.), 2009. Aparat bezpieczeństwa Polski Ludowej wobec mniejszości narodowych i etnicznych oraz cudzoziemców. Warszawa: Instytut Pamięci Narodowej.

SzCZepankiewicz-BATtek J., 2001. The multicultural character of east Lusatia and its role in cross-border cooperation [in:] M. Koter, K. Heffner (eds.), Changing role of border areas and regional policies, Region and Regionalism, no. 5, OpoleŁódź: University of Łódź. Department of Political Geography and Regional Studies, Silesian Institute in Opole, pp. 100-104.

SzCZEPANKIEWICZ-BATtek J., 2003. Lusatian Sorbs the smallest nation of Central Europe [in:] M. Koter, K. Heffner (eds.), The role of ethnic minorities in border regions, Region and Regionalism, no. 6, vol. 1, Łódź-Opole: University of Łódź. Department of Political Geography and Regional Studies, Silesian Institute in Opole, pp. 55-59.

SZCZEPANKIEWICZ-BATTEKJ., 2005. Łużyce - przestrzeń dysocjacji kultur narodowych i religijnych. Słupsk: Pomorska Akademia Pedagogiczna w Słupsku. 
SzCZYGIELSKI K., 2006. Geografia mniejszości narodowych i etnicznych w Polsce. Ujęcie ilościowe. Opole: Instytut Śląski w Opolu.

SzMeJA M., 2005. Czy Ślqzacy sq narodem [in:] M. Malikowski, D. Wojakowski (eds.), Granice i pogranicza nowej Unii Europejskiej. Z badań regionalnych, etnicznych i lokalnych, Kraków: Nomos, pp. 158-171.

TARKA K., 1998. Litwini w Polsce 1944-1997. Opole: Wydawnictwo Uniwersytetu Opolskiego.

ToBjański Z., 1994. Czesi w Polsce. Kraków: Towarzystwo Społeczno-Kulturalne Czechów i Słowaków w Polsce.

TOMASZEWSKI J., 1985a. Rzeczpospolita wielu narodów. Warszawa: Czytelnik.

TOMASZEWski J., 1985b. Ojczyzna nie tylko Polaków. Warszawa: Młodzieżowa Agencja Wydawnicza.

TomaszeWSKI J., 1991. Mniejszości narodowe w Polsce w XX wieku. Warszawa: Editions Spotkania.

Tomaszewski J. (ed.), 1993. Najnowsze dzieje Żydów w Polsce. Warszawa: Wydawnictwo Naukowe PWN.

URBAŃSKI Z., 1932. Mniejszości narodowe w Polsce. Warszawa: Wydawnictwo Mniejszości Narodowe.

WAKAR W., 1917-1918. Rozwój terytorialny narodowości polskiej. Vol. 1: Statystyka narodowościowa dzielnicy pruskiej i austriackiej. Vol. 2: Statystyka narodowościowa Królestwa Polskiego. Vol. 3: Statystyka narodowościowa kresów wschodnich. Kielce: St. Święcki.

WaldenberG M., 1992. Kwestie narodowe w Europie Środkowo-Wschodniej. Warszawa: Wydawnictwo Naukowe PWN.

Waldenberg M., 2000. Narody zależne i mniejszości narodowe w Europie Środkowo-Wschodniej. Dzieje konfliktów i idei. Warszawa: Wydawnictwo Naukowe PWN.

WARMIŃSKA K., 1999. Tatarzy polscy. Tożsamość religijna i etniczna. Kraków: Universitas.

WASILEWSKI L., 1917. Kresy Wschodnie. Warszawa-Kraków: Towarzystwo Wydawnicze w Warszawie.

WASILEWSKI L., 1925. Litwa i Białoruś. Zarys historyczno-polityczny stosunków narodowościowych. Warszawa-Kraków: Towarzystwo Wydawnicze w Warszawie.
WASILEWSKI L., 1927. Istotna liczba Ukraińców w Polsce. Sprawy Narodowościowe, 5-6, pp. 227-236.

WASILEWSKI L., 1929. Sprawy narodowościowe w teorji i w życiu. Warszawa-Kraków: Towarzystwo Wydawnicze w Warszawie.

Wasowicz J., 1927. Narodowości Rzeczypospolitej Polskiej według spisu z 30 września 1921. Lwów-Warszawa: Główny Urząd Statystyczny.

WasoWICZ J., 1928. Polacy na Ukrainie w świetle ostatniego spisu ludności. Czasopismo Geograficzne, vol. 6, no. 1, Łódź-Warszawa, pp. 18-28.

WiATR J., 1973. Naród i państwo. Socjologiczne problemy kwestii narodowej. Warszawa: Ksiqżka i Wiedza.

Wojakowski D., 2002. Polacy i Ukraińcy. Rzecz o pluralizmie i tożsamości na pograniczu. Kraków: Nomos.

WoJeCKI M., 1975. Ludność grecka w Polsce Ludowej. Przegląd Geograficzny, vol. 47, no. 4, pp. $763-768$

WYsocki J., 2011. Ukraińcy na Lubelszczyźnie w latach 1944-1989. Lublin: Instytut Pamięci Narodowej.

WYSOCKI T., 2006. Osoby niepolskiej narodowości i języka w Polsce w świetle NSP 2002. Studia Demograficzne, 2/150, pp. 96-125.

WYSOCKI T., 2010. Zmiany w strukturze narodowościowej mieszkańców Polski w XX wieku i ich konsekwencje dla procesów demograficznych. [Typescript in the Library of the University of Łódź].

ZABORSKI B., 1937. Liczba i rozmieszczenie mieszkańców Polski według języków i wyznań (uwagi ogólne w świetle spisu 1931 r.). Sprawy Narodowościowe, vol. 11, no. 1-2, pp. 75-86.

ZABORSKI B., WrZOSEK A., 1937. Antropogeografia [in:] Wielka geografia powszechna, vol. 3, Warszawa: Dom Wydawniczy Trzaska, Ebert i Michalski.

ZnANieCKI F., 1990. Współczesne narody. Warszawa: Państwowe Wydawnictwo Naukowe.

ŻELAZNY W., 2004. Etniczność. Ład-konflikt-sprawiedliwość. Poznań: Wydawnictwo Poznańskie.

ŻokęDOWSkI C., 2003. Białorusini i Litwini w Polsce, Polacy na Białorusi i Litwie. Uwarunkowania wspótczesnych stosunków między większościq i mniejszościami narodowymi. Warszawa: Oficyna Wydawnicza Aspra-JR. 
http://rcin.org.pl 